\title{
LAND CONSOLIDATION AS AN INSTRUMENT OF SHAPING THE AGRARIAN STRUCTURE IN POLAND: A CASE STUDY OF THE WIELKOPOLSKIE AND DOLNOŚLĄSKIE VOIVODESHIPS
}

\author{
IWONA MARKUSZEWSKA
}

Institute of Physical Geography and Environmental Planning, Adam Mickiewicz University in Poznań

Manuscript received: March 20, 2013

Revised version: July 5, 2013

\begin{abstract}
MARKUSZEWSKA I., 2013. Land consolidation as an instrument of shaping the agrarian structure in Poland: a case study of the Wielkopolskie and Dolnośląskie voivodeships. Quaestiones Geographicae 32(3), Bogucki Wydawnictwo Naukowe, Poznań, pp. 53-67. 1 table, 2 figs. DOI 10.2478/quageo-2013-0027, ISSN 0137-477X.

AвSTRACT. Fragmentation of agricultural landscape is a specific feature of agrarian structure in Poland. Despite the fact that consolidation work has been carried out for years, the positive effects are still negligible. This is because land consolidation in Poland is encountering with a number of obstacles, which on the one hand, is cumbersome formal and legal policy, and on the other hand, disapproval of officials and farmers as well. These barriers unnecessarily prolong the proceeding, which is inherently long-term, sometimes takes years and not always is successfully completed. For this reason an effort was made to answer the question: how improving in land consolidation policy may look up the efficiency of land merging work in Poland? Two formal procedures were presented, on the basis of which land consolidation is carried out in two voivodeships: Wielkopolskie and Dolnośląskie. The study revealed the main obstacles and weaknesses in legal regulation. Additionally, open-interviews among farmers as well as local and regional land consolidation authorities, were undertaken. On the basis of the acquired data, a number of new suggestions to more successful land consolidation policy, were put forward. Finally, possible solutions to perk up the land unification work were established.
\end{abstract}

KEY WORDS: agrarian structure, land fragmentation, patchwork, chessboard, plot distribution pattern, Wielkopolskie and Dolnośląskie voivodeships.

Address of the corresponding author: Iwona Markuszewska, Institute of Physical Geography and Environmental Planning, Adam Mickiewicz University in Poznań, Dzięgielowa 27, 61-680 Poznań, Poland; e-mail: iwmark@amu.edu.pl

\section{Introduction}

Small-size of fields or parcels scattered in different parts of agrarian space are economically unjustified and hence, thanks to grouping tiny units the production effectiveness can be enhanced, what was detailed in van Dijk (2003) and Woch (2006). Furthermore, Miranda et al. (2006) pointed out that land consolidation is a very useful tool in rural planning and management by improving farm productivity through easier mechanization and reduction of transport costs. Additionally, in recent years it has been risen the role of land merging as an assistance instrument in creation of integrated development of rural areas (FAO 2003, Thomas 2006), where improving life quality within countryside are expected to achieve. It is worthy to mention that after a highly criticism of traditional simple land consolidation, in a view of harmful environmental consequenc- 
es (Grossman, Brussaard 1992), comprehensive land merging, with more landscape and nature valuable outlook, was put into practice.

Land consolidation leads to land parcels merging and swapping, plots exchanging to forms that are better adjusted to their proper use, however, this operation has a broader range of significance. In the literature there are mentioned two different ways of land consolidation, namely: simple or compulsory land consolidation and comprehensive or complex land consolidation (Sonnenberg 2002, Vitikainen 2004). The former one is understood as only land merging work connected with improving the agrarian production efficiency. The latter one, apart from farmland grouping and swapping, includes among other: implementation of a new water management system, balks and pathways network, renewal of roads infrastructure, implementation of landscape elements preventing of erosion as well as enhancement of landscape and nature protection. The main reason of introducing all these agrarian-arrangement work is to create a better living condition as well as protect and improve the environment within rural areas (Act of 26 March 1982 on Land Consolidation and Exchange). Additionally, land consolidation is an appropriate instrument for introducing non-production functions within rural areas, what stands very close to the idea of multifunctional development of countryside. Together with that, the objectives of land consolidation were incorporated with social, ecological and cultural aspects (Meuser 1992, Tenkanen 1994).

One of the aspect, describing the level of land fragmentation, is farm size. Although, there is no universal premise as for the most favourable farm area (Woch 2001), there is no doubt that this is a key factor, most often limits farm development (Bartolini, Viaggi 2013). In addition to this, it has been proved that larger farms obtain higher incomes than smaller ones (Deininger et al. 2004). Moreover, a small field size is put forward with respect of the greatest difficulties in farmland cultivation. However, land fragmentation also relates to:

1) a huge number of land plots spread in different parts of farmland,

2) a really inconvenient fields' shapes and their awkwardly placed, and
3) a very remote distance between farmland and farmstead (van Dijk 2007).

It is estimated that the last one is the most troublesome here, because it generates transport, labour and production costs, rising proportionally to the length increase. For instance, landowners with an unfavourable land distribution pattern can lose up to $20-30 \%$ income derived from agricultural activities (Wierzchowski 2007). More examples of negative economic consequences of inconveniently land pattern, can be found in Vranken et al. (2004).

The arguments presented above prove the importance of land pattern in relation to production efficiency, but it depends not only on them, because there are another driving factors, where high soil quality comes out on top. First-class farmland is especially important within areas, where agriculture plays a significant role, what in respect to Central and Eastern European Country should be really imperative, taking into consideration that arable land comprise here over 50\% of total areas (Pasakarnis, Maliene 2010). Owing to this, within these areas the best condition for cultivation should be created.

Many rural areas of European countries suffer from land fragmentation, however, this problem is really acute in Central and Eastern Europe (van Dijk 2007), where Poland stands out from other countries. The current landscape structure in these states is a consequence of farmland reforms that have been taken place over the postwar period. Firstly, after 1945, it was land nationalisation and agriculture collectivism, and after when the communism system collapsed, at the beginning of the 90s. - land ownership restitution. Transition from central managed to market economy, linked with farmland privatization or re-privatization, led up to increase the level of land disintegration. In fact, large-sized farms, being previously under state management, had been split up into a large number of tiny, about one hectare, plots and purchased by great deal of private owners. Fortunately, the situation is not so dramatic in every country. For comparison: Slovakia and the Czech Republic have the best land-use structure, because three-quarters of all agricultural land is under large units (Voltr 2000, Kabat, Hagedorn 1997). In contrast, in Romania, Bulgaria and Poland more than half of all 
agricultural land is used in units smaller than 2 ha (Benedek 2000). It should be emphasised that in Poland, and also in former Yugoslavia, during the socialist era, strong farmers' opposition had faced with common farmland nationalization, and in effect of that, private family farms dominated here, however, the average land belonged to them usually not exceeded 5 hectares. Except that type of undersized private land owners, there were largeness state agriculture farms (pol. państwowe gospodarstwa rolne, sovhoses) as well as agricultural cooperatives (pol. spóldzielnie rolnicze, kovhoses). Nonetheless, it does not change the fact that present fields' patchwork, shaped by various factors, but mostly effected by tradition and historical conditions, is a huge barrier in cultivation.

These days in Poland, land fragmentation, socalled as fields' patchwork or chessboard, is usually described by plot distribution pattern, which relates to:

1) a small average size of a farm (7 ha),

2) a relatively high number of land plots per one farm (8 pieces),

3) a small average size of the individual plot (0.6 ha).

Furthermore, the distance between the farm and cultivated fields can be considerably remote, sometimes reaching up to 3 and even $4 \mathrm{~km}$ (Woch 2006). However, a variant degree of agrarian pattern fragmentation, in relation to spatial distribution, is influenced largely on historical and social factors affecting over the last two centuries. At present, the largest farms occur within northern and western parts of the country, for example, the average area in the Zachodniopomorskie Voivodeship is around 23 ha, in Warmińsko-Mazurskie - 19 ha, and in Pomorskie - 16. That area after Poland division had been taken by the Prussians, where large-scale land properties were created. After 1945, on the basis of those farmland ownerships, state farms were established. At last, after socialist system collapsed, as a result of economic changes the farmland was purchased by private owners or tenanted from the Agency of Agricultural Property, still maintaining a considerable acreage (Markuszewska 2013). In contrast the most unfavourable agrarian structure occurs in south-eastern Poland, in voivodeships: Małopolskie, Podkarpackie and
Lubelskie, where negligence with regard to modernization of farming techniques, evidently seen during the division period, as well as failures of attempts to land consolidation, undertaken after peasants enfranchisement (Wierzchowski 2007), consequently contributed to the current level of land fragmentation. Additionally, not without significance is a very high density population, what corresponds to a great number of dwarf family farms with a tiny average acreage: in Małopolskie - 2.9 ha, in Podkarpackie - 3.2 ha, in Lubelskie - 6.4 ha. As for the fragmentation of agricultural land, it should be noted that it is mainly the result of: inheritance division, land purchase, and also diverse topography, which is the main obstacle in mountain regions, as well as the soil diversity, especially troublesome in lowlands. According to estimated data (Woch 2006), the average plot size in above mentioned voivodeships is $0.3 \mathrm{ha}, 0.4$ ha and $0.6 \mathrm{ha}$, respectively.

In all probability it would not be a point for a broad discussion if this situation would related to a country, where agriculture is negligible. Nonetheless, in Poland the agriculture as an economic sector, plays a very important role: it employs $17 \%$ of labour force and arable land covers about $60 \%$ of the total land (Statistical Yearbook of Agricultural, 2011). Unfortunately, the contribution of agriculture in GDP is only 3\%, what shows low efficiency of farmers' production. Even so, the share of small-scale family farms, with area less than 1 ha, is about $30 \%$, where large holdings, occupying more then 50 ha, take only $1,2 \%$. Although Polish holdings' sizes are very similar to some of the EU members, such as: Italy, Portugal or Greece, it must be said that agriculture has got there only a little economy importance. On the other hand, taking into account the fact that low efficiency of farmers' production is a result of inconvenient land pattern, the land consolidation by enlarging and creating more compact fields, seems to be the best way to deal with land fragmentation in Poland.

The agrarian pattern in Poland has always been characterized by a high fragmentation, and even so in the past attempts to dismantle this obstacle had been made frequently, the problem with fields' chessboard still exists. Moreover, bearing in mind the positive effects of fields' patchwork liquidation, it seems to be surprising 
that land merging in Poland is not a commonly used tool for improving the production efficiency. On the contrary, the rate of merging-replacement works has been declining systematically during the post-war period. Until the 1980s. about 300-400 thousand ha was merged annually, when in the 1980s. the rate decreased to 30-100 thousand, while in the 1990s. it dropped to almost zero (Woch 2001). The situation has improved slightly after the Polish accession to EU, because thanks to the financial support it was possible to continue merging work. During 19992012 in four leading voivodeships: Lubelskie, Małopolskie, Podkarpackie and Podlaskie, about 70 thousand ha of land had been consolidated. Nevertheless, the statistics are alarming, because assuming that the rate of land merging will be at the level of the last 10 years (10 thousand ha per year), it will take 400 years to amalgamate 4 million ha of agricultural land, which suffer from the highest fragmentation. Among the reasons of this process failure the following driving factors should be pointed up: 1) decreasing funds, 2) adverse legislation, and 3) farmers' unwillingness (Woch 2006, Wierzchowski 2007).

It should be added that at present, in Poland land consolidation process is regulated by the Act of 26 March 1982 on Land Consolidation and Exchange (hereinafter referred to as the Act), and additionally, on the Instruction on Land Consolidation (Instruction No. 1 of the Agriculture and Food Minister on land consolidation), which as a supplementary document regulates the technical issue of merging works. Moreover, in relation to the rules of spatial planning, administrative bodies responsibilities and power, some other legal acts play important role in carrying out the land consolidation process, i.e.: the Act of 27 March 2003 on Spatial Planning and Development, the Act of 5 June 1998 on Province Government and the Act of 8 March 1990 on Local Government. It is worthwhile mentioning here that the first piece of legislation, which solved the problem of inconvenient scattered field parcels in Poland, after regaining the independence in 1918, was the Act of 31 July 1923 on Land Consolidation. This Law was amended several times, however, remained in force until 1968, when it was eventually repealed by the new Act of 24 January 1968 on Land Consolida- tion and Exchange. In 1982 the new law came into force.

As for the funding sources of land consolidation works, the rule is the following: at least $25 \%$ comes from the state budget, while the remainder, but a significant contribution, is derived from European Union support. Between 2004-2006, these activities were funded under the Sectoral Operational Programme "Restructuring and Modernization of the Food Sector and Rural Development", Measure 2.2. 'Land re-parcellling'. In the years 2007-2013 it has been caring out in the framework of the Rural Areas Development Programme, Axis 1 - "Improving the competitiveness of the agricultural and forestry sector", Scheme I - "Land Consolidation". It has been defined the maximum bids that can be used per 1 ha of merging land. For the voivodeships of Lubelskie, Podkarpackie, Małopolskie, Śląskie and Świętokrzyskie estimated amount is 1,400 euro, while the others voivodeships $-1,250$ euro per hectare. The differentiation in rates is justified by the fact that the cost of land consolidation conducting within the first group is higher, because those regions are characterized by a very problematical fields' patchwork and difficult topographical conditions. Allocation of the financial resources between the provinces has been made in order to the total area of objects submitted to land merging as well as the index of land relief differentiation. According to that, for years 2007-2013 a greatest pool of subsidies has been granted to Lubelskie - 33,972,000 Euros, and the lowest one to Pomorskie - 1,520,000 euro. As for the analyzing in this paper voivodeships, Dolnośląskie received 13,193,600, whereas Wielkopolskie only $1,976,000$.

Taking into consideration all above facts, the aim of this paper was threefold:

1) to indicate the weaknesses of land consolidation policy, which as legal grounds are obstacle of efficient course of land merging process,

2) to point out how agrarian-arrangement plans of communes, as a spatial planning instrument, may improve the comprehensive management and development of rural areas in respect to land consolidation,

3) to propose a new approach of land consolidation, which is likely to solve the problem with 
dismantling of inconvenient fields' patchwork.

A special attention was put on legal policy aspect, because in the opinion of the author, this is the main reason of failure of land merging proceedings. The broad discussion undertaken in this paper was focused particularly on these aspects which can remedy the current situation. For finding the solution the linking between social, administrative, economic, on the one hand, and policy, on the other hand, was made. For appropriate efficiency assessment of two different approaches, on the basis of which land consolidation process is executed nowadays, in two voivodeships were chosen. It should be pointed out that the selected voivodeships are not representative in regard to the highest land fragmentation, because in this case the role model would be Lubelskie, for example. However, similarities in condition of agriculture development as well as agrarian structure, and simultaneously completely different way of land consolidation conducting, were decisive in the selection of these study regions. In the Wielkopolskie Voivodeship, the conventional land consolidation policy is set in motion, and in contrast, in the Dolnośląskie Voivodeship, the alternative way is practising.

It should be added that in this article the land consolidation relates only to farmland adjunction; land consolidation for non-agricultural purposes, as a part of highway infrastructure re- alisation as well as forest compactness, was not mentioned here.

\section{Material, methods and case study}

In this paper, the detailed investigate steps, in relation to the main purposes and research framework (Fig. 1), were sorted into several categories. The starting point was to analyse the legal acts describing both, the land consolidation procedures and spatial planning policy relating to agrarian production space. Additionally, a broad outlook of current farmland fragmentation and agricultural landscape pattern was gained from corresponding literature supplemented with comprehensive statistical data. After that, open-interviews among farmers as well as local and regional land consolidation authorities, were undertaken. On the basis of the acquired data, a number of new suggestions to more successful land consolidation policy, were put forward. Finally, a view-point about the future of Polish fields' patchwork, as an element of traditional agricultural landscape, was come up for extensive discussion.

The questions addressed to farmers from selected villages from the Wielkopolskie Voivodeship related to:

1) their attitude to land consolidation and exchange,

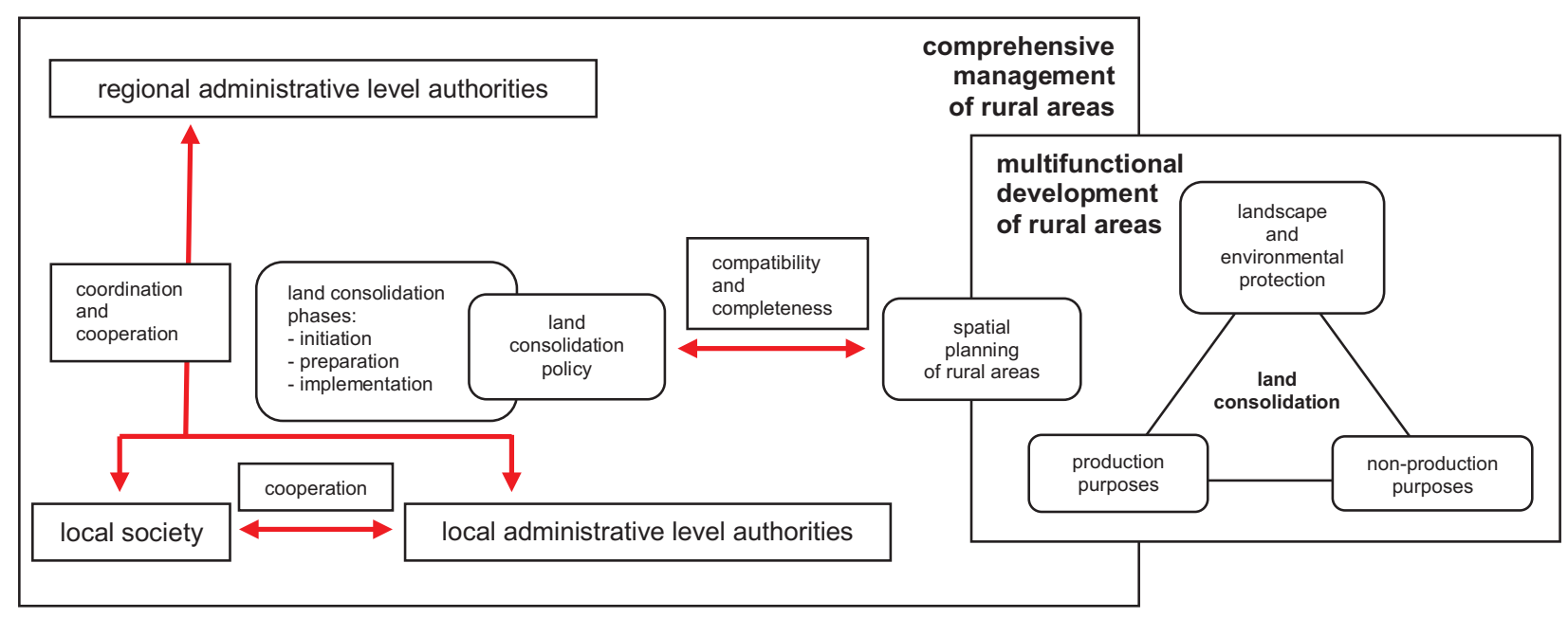

Fig. 1. The research framework - land consolidation in relation to management and development of rural areas. The relationships between stakeholders of land consolidation process as well as spatial planning policy of rural areas have been marked by the red arrows 
2) their knowledge about procedures of land merging, especially about initiation stage, and

3) their positions in contribution in costs.

In contrary, enquiry addressed to local and regional administrative bodies of the Wielkopolskie Voivodeship, represent authorities of local spatial planning and land consolidation proceeding, content information about:

1) involvement in promoting within farmers the idea of land consolidation,

2) accountability of various administrative bodies in the area of preparation and implementation of land merging work, and

3) attitude toward current land consolidation legislation and policy.

Bearing in mind the fact that all land consolidation procedures start off at the local level, and end up at the regional one, in other words, the policy relates to the administrative area of the voivodeship (province), for research conducting two of them, Wielkopolskie and Dolnośląskie, had been chosen. These study areas were selected to represent the most contrasting examples, in terms of land consolidation policy manner, where a commonly used bottom-up option in Wielkopolskie is established, while an alternatively top-down path in Dolnośląskie is executed. Furthermore, the decision was supported by another reasons:

1) dissimilar demand of farmland merging (in Wielkopolskie only $15 \%$ of the area should be merged, in Dolnośląskie - even 40\%),

2) different importance of agriculture (in Wielkopolskie dominates highly commodity farming, in Dolnośląskie - median one), and

3) different natural condition of agriculture development (in Wielkopolskie is much more favourable than in Dolnośląskie).

The essential characteristics of these two provinces, especially in relation to plot distribution pattern, are presented in table 1.
Presented in this paper the conventional way of land merging, which was broadly discussed in regards to frailty of the legal foundation and with relation to the previously existing body of laws, was enriched by the information gathered from open-interviews data. On the other hand, the attention in the alternative variant, based on legal procedure of the Act of 17 May 1989 of the Geodesic and Cartographic Law, was focused on multi-stages analysis of arranging-agrarian plans of communes, which as documents describing agrarian area, are a useful tool for land consolidation setting up.

\section{Results}

\subsection{Land consolidation - the commonly used approach}

\section{The petition stage}

According to the regulation, land consolidation procedure is set in motion on land owners' formal requests. The Act states that the process is initiated only with the consent of the majority of farmland owners, or at the request of these ones, whose total land is more than a half of the area proposed to be merged. It should be added that legislation also gives an opportunity to ex officio consolidation process conducting. In regards to private landownership it concerns situation, where an application is submitted by a farmer, whose land parcels should be relocated, however, it cannot worsen economic conditions of other land owners. This way of land consolidation, due to a very narrow range of possibilities, is hardly never practically used.

At this juncture the first obstacle appears, because as open interviews revealed, farmers have only a little awareness of the subsequent facts: consolidation work is carried out on their own

Table 1. The main statistical characteristics of research areas prepared on the data from the Local Data Bank and Woch (2006)

\begin{tabular}{|c|c|c|c|c|c|c|}
\hline \multirow[b]{2}{*}{ Voivodeships } & \multirow{2}{*}{$\begin{array}{c}\text { Share of agri- } \\
\text { cultural land } \\
\text { in total area } \\
{[\%]}\end{array}$} & \multicolumn{2}{|c|}{ Share of farms [\%] } & \multicolumn{3}{|c|}{ Plot distribution pattern } \\
\hline & & up to 1 ha & over 50 ha & $\begin{array}{c}\text { Average farm } \\
\text { area [ha] }\end{array}$ & $\begin{array}{l}\text { Average num- } \\
\text { bers of plots } \\
\text { per farm }\end{array}$ & $\begin{array}{c}\text { Average area } \\
\text { of single plot } \\
\text { [ha] }\end{array}$ \\
\hline Wielkopolskie & 60 & 23.8 & 2.2 & 12 & 3.9 & 1.4 \\
\hline Dolnosląskie & 49 & 41.0 & 2.5 & 11 & 4.7 & 1.5 \\
\hline
\end{tabular}


initiatives, as beneficiaries they do not have to bear any costs, and with land merging is linked village infrastructure improvement. What is conspicuous here, many of interviewed farmers, for whom farming is the only one source of incomes, argue that lack of this knowledge prevent them from taking any particular actions. Interesting how a difference of opinion on this one have dual-worked farmers, practising hobby farming within their micro-farms, who are strong opponents always funding the excuse to prolong the land merging procedures. Moreover, it needs to be noted that not the farmers' age, but their attitudes to land using is a hindrance to agrarian structure reorganization, because unwillingness to holdings enlarging appears at farmers being at varied ages, not only in the elderly ones, what should be expected.

Alternatively, representatives of district administrative bodies (departments of geodesy, cadastre and cartography), being in charge of land consolidation, do not carry out any information campaigns among farmers to promote the idea of agrarian pattern improvement, explaining their disinclinations in lack of the duty in this matter. According to the study results, officials are willing to renounce participating in land consolidation proceedings, however, they do not speak out, giving only understanding that this task comes from legal requirements and for this reason they only focus on necessary work. They argued that this is pol. sottys (a head of the village), who with a good knowledge with the local community, should be responsible for encouraging farmers.

Analyzing the following procedure, another barrier can be found. After the positive opinion of the formal request, the Decision to initiate the land consolidation or exchange is taken by the starost, who as a head of the district government, is authorized to conduct the proceeding. It should be noted that in 1998 in Poland the administrative system was modified. In agreement with a new division, at the local government two levels were distinguished: at the first level - a municipality, and at the second one - a district, which includes several municipalities (the Act of 13 October 1998 - Regulations Implementing the Act Reforming Public Administration). That was linked with a new distribution of responsibilities, because before the reorganization, land consolidation proceedings were conducted by the wojt, a head of commune government, and after reorganization, the competence was moved to the starost. However, maintaining this task under municipal government power would be more appropriate, due to the fact that this authority is responsible for development and management at the local level, so among others, within rural areas (the Act of 8 March 1990 on the Local Government of). Omission of this administrative body, even as an advisory one, in a such important activity like shaping of spatial structure of rural areas, is inadequate. With this statement agreed interviewed officeholders, who admitted that they would take the responsibility of carrying out the merging process at the preparation stage.

\section{Planning, negotiation and decision-making stage}

After the Decision is issued, further procedures can be activated, for which the provincial government is authorized. At this stage, a land consolidation project is elaborating, by a surveyor-designer from geodesy department, under advisory supervision and constant consultation with landowners. Although the project is drafted by the surveyor-designer, this is the starost, who is entrusted to approve this document, when after public presentation, the majority of participants did not submit objections, and then all of them accepted it unreservedly.

In a case of social consulting, a very strong role has a land consolidation committee, which consists of: board of participants nominated by farmers as well as representatives of various organisations and authorities nominated by the starost. Besides, when there are quarrels between the participants about unfavourable farmland exchange and valuation, for solving problems experts' council is appointed.

A broad influence of landowners prolongs procedures and in extreme cases leads even to breaking down the negotiations, because: draft land consolidation project can be endlessly comment, starost's provision can be undermine at whatever time, and procedures can be easily prosecuted to the administrative court. It must be clear explained that the landowners contribution is advisable, yet, if it is necessary administrative decisions should be undeniable. 
One of a good example of that kind of activity can be observed in Brudzewek, the only one village in the Wielkopolskie Voivodeship, where the land consolidation procedure is carried out right now. Within the area of 280 ha 37 farmers are farming. The farms are very small, their acreage is between 1 and 5 ha, and in addition, each farm is divided into average 20 parcels. However, one farmer posses his 37 ha of land spread into 121 pieces. Taking into account the level of land fragmentation, parcel relocation and field enlargement is unquestionably needed here. Though, the efforts to improve the agrarian structure have been caring for over 20 years, it is still open the question if it will be successful, due to increasing number of objections of the landowners. Most of them are interested in obtaining the highest possible financial recompense for land exchange, instead of taking care of receiving land with better soil quality. This is because they treat agricultural land as collateral, minor source of incomes.

Apart from above facts, for better understanding the conservatism of Polish farmers and their reluctance to both, land merging and making a new allocation of parcels, interviews results can be helpful. This lack of enthusiasm is associated with: a strong emotional relation to the patrimony, a lack of trust in officials, who try to persuade farmers to land relocation, and a negative perception of a new proposition of land relocation. Even if farmers are aware of some economic benefits that would be achieved through land merging, as long as the productive value of current land patchwork is acceptable for them, it is not easy to convince them about land relocation. Additionally, land consolidation and post-consolidation management is unfortunately improperly understood by farmers, who all these activities treat as only as simple parcel grouping and exchange their locations.

There is no doubt that for procedure's streamlining the modification in current over-liberal regulation must be done. As for example, according to the Act of 1923, land consolidation authorities had permission to intervene when the merging committee acted inconsistently with the law. In that situation it was possible to dismissal all members and to appoint new ones, chosen by the officials. At this moment, it is impossible, even if the advisory group exceeds its power, because these are only landowners who have permission for it. Nevertheless, the most important was the fact that the interruption of the ongoing process was really hampered and only possible if the application was submitted of two-third of participants. Moreover, in such cases, only the persons responsible for procedure deferral were imposed of the cost of previously done work. Nowadays, the unification procedure can be suspended or stopped at the request of the only one farmer, regardless of how advanced the merging work is. Additionally, what is difficult to accept, the person does not bear any expenditure for already executed investments.

In regards to drafting the land consolidation project, another fact has to be taken into consideration. This project should refer to principles of local spatial policy, such as local spatial development plans and study of conditions and directions of spatial development. It brings considerable perturbations when for the area prepared to be merged no local plan had been drafted, or the existing one contains guidelines which are in opposite to the project. It is very important, because implementation of the inconsistent project makes it invalidated, even when some tasks had been already put into effect. On the other hand, modification of the local plan or adjustment of the project to the requirements of the existing local plan, prolongs the merging process.

\section{Implementation stage}

The implementation of land consolidation project is carried out in two phases. The first one, concerning land parcels joining and relocating, is fully completed by the geodesy department. In contrary, the second phase, including post-consolidation management, is under the starost supervision, who selects a contractor during tendering procedure. Separation of coordinating and implementing competencies between two different levels of administrative governments, is not recommended, what admit representatives of land consolidation authorities. However, they are not able to indicate unambiguously which kind of authority should possess the exclusiveness.

The execution of all planned engineering work and post-consolidation management is associated with expenses, which are covered by the 
state budget. Even though, the Act mentions of the possibility of land owners' participation, it points out that it is not obligatory, what in practice means that the participants do not show any interest in costs contribution. This provision is highly controversial and debatable. It is all the more surprising when taking into account the fact that the merging land belongs to the private owners. It should be emphasized that the both earlier Acts, of 1923 and 1968, imposed an obligation to participation of all the farmers in proportion to the acreage held under consolidation. Additionally, as was previously stated, nowadays the costs do not bear even these of landowners, who broke the negotiations and procedure merging.

\subsection{Land Consolidation - the non-statutory option}

\section{Arranging-agrarian plans of communes}

The alternative procedure is based on arranging-agrarian plans of communes, and for better understanding more information about these documents should be given.

At the local level the spatial planning policy is completed according to: studies of conditions and directions of spatial development of communes and local spatial development plans (The Act of 27 March 2003 on Spatial Planning and Development). Except them, there are other, so-called as "strategic" documents, as for example: development strategies, local development plans and environmental protection programs. However, all of them, but especially the first two, refer to area allocated for typical investment purposes. Despite the fact that the study includes guidelines of management of the agronomic production area and also marks out intending areas for non-agricultural use, there is no recommendation relating to intensively used agrarian space not changing its purpose. This gap is filled with other papers, such as arranging-agrarian plans of communes (plany urzadzeniowo-rolne gmin) and arranging-agrarian projects of villages (projekty urzadzeniowo-rolne wsi), which thanks to a wide range of multidimensional characterization, are appropriate tools for rural landscape planning. Nevertheless, it should be clearly highlighted that both, plans and projects, are a separate group of strategic documents, used as tools for planning of arranging-agrarian works, and for this reason they are inappropriate in spatial planning decision making process.

Another important fact is that a regulation for plans drafting (The Act of 8 March 1990 on Local Government), which allows to local economic programs passing, gives the authority to the province geodesy department (the Act of 17 May 1989 on the Geodesic and Cartographic Law). Yet, as until now there have not been prepared the legal basics regulating principles of these document preparation. From the practical point of view it means that there is no obligation to draw up them, although the plan becomes a local normative act, when its provisions, as a resolution of the municipal council, is passed to implementation.

The plan lists a wide range of work leading to improving the farming effectiveness with simultaneously maintaining of environment quality, where for achieving proposed goals transition of landscape structure ought to be done. When it comes to utility public infrastructure, roads renovation and plumbing system setting, are emphasized here as well. Among the information related to description of the plot distribution pattern, the subsequent are giving: number of parcels within an individual farm, size of the individual parcel, and distance between farmstead and arable land. Due to this fact, the plan stands out from other local strategic documents as a useful tool in assessment of land consolidation demand (the Analysis of demand ... 2010).

The guidelines of the plans constitute directives on drafting the arranging-agrarian projects of villages. Similarly as in plans, also in projects the issue of an appropriate composition of the plot distribution pattern is pointed up. As for the land merging, a wide range of information relating to agrarian structure can be found. Furthermore, suggestions about landscape conservation are marked out, for instance: afforestation of unfertile soil, establishing of mid-field shrubs preventing wind erosion, introduction of mid-field balks and other linear landscape elements purifying ground water, and delineation of non-cultivated refuges for biodiversity increasing. However, what marks out these projects is a great 
practical importance in application for financial subvention receiving from the EU budget from the Rural Areas Development Programme, Axis 1 - "Improving the competitiveness of the agricultural and forestry sector", Scheme I - "Land Consolidation" (the Analysis of demand ... 2010).

\section{Analysis of demand for land consolidation work in villages of the Dolnośląskie Voivodeship}

The geodesy department of the Marshal's Office of the Dolnośląskie Voivodeship elaborated documents' collection, inclusive with: the Analysis of demand for land consolidation work in communes, the Study of demand for land consolidation work in the province as well as the Database of land consolidation objects.

As for the Analysis, compiled between 20022010 in accordance with the identical directives, 96 arranging-agrarian plans of communes, covered 1793 villages, were the basis of investigation into land merging demand. It is vital to know that not only characteristic of the plot distribution pattern, but also useful information about farmers' approvals of land merging had been possessed from the plans. Moreover, for urgent merging it was qualified agricultural land: characterized by the highest land fragmentation with simultaneously rich soil quality, the area with relatively large average farm size that makes merging workable and profitable, farmland considerably outlying from farmsteads, and area with loads number of mid-field roads hampering cultivation. It was also analyzed, whether defective agrarian structure appeared only in a few villages or this problem occurred in a significant area of the commune, where the letter had got priorities. Furthermore, regions of diverse intensity of agronomic function had been distinguished, what helped to eliminate potential consolidation work performing within poor quality farmlands, where implementation of tourism would be more suitable there, for instance. Likewise, strong large-scale mining pressure and other industrial activities forced a necessity of less intense agricultural land use and renouncement of land merging execution. In addition, the aim of the Analysis dissemination was twofold: on the one hand, to increase farmers' awareness of land consolidation and other arranging-agrarian works benefits, and on the other hand, to create proper conditions for information flow between all administrative bodies involved in grounding, coordinating and conducting of consolidation and exchanged works.

After proceedings ended up, the Analysis was introduced into the Study of demand for land consolidation work in the Dolnosląskie Voivodeship. On the next step, villages characterized by the highest land fragmentation had been chosen to possible merging. After that, 499 objects recommended to consolidation work, had been included into the Database. Yet eventually, only 9 of them had been selected to work realization, carried out between 2007-2013.

\subsection{Land consolidation - looking for the best solution}

The alternative option, presented above, is definitely better prearranged in terms of essential aspects of land consolidation proceedings than the standard practices. Moreover, this outlook emphasise the role of multifunctional development of rural areas, what reflects the methodological framework of the research approach proposed in this paper (see Fig. 1).

A new resolution provides strength for commune government, as the body responsible for spatial planning, management and development of the rural areas, giving to it the opportunity for shaping the comprehensive box of strategic and planning documents, in which arranging-agrarian plans and projects are missing in this days. All gathered data, regarding to arranging-agrarian works, with special emphasis on land merging, would be handed over to the province geodesy department, which role would be to develop wide-ranging study of land consolidation demand in the given voivodeship. This approach, thanks to involvement the municipal offices in planning and decision-making process, and simultaneous removal district administrative body, also allows improving the proceedings (Fig. 2). The strong argument for decentralization is the interest of communities in comprehensive management and planning rural areas, what was emphasized over the interviews. 


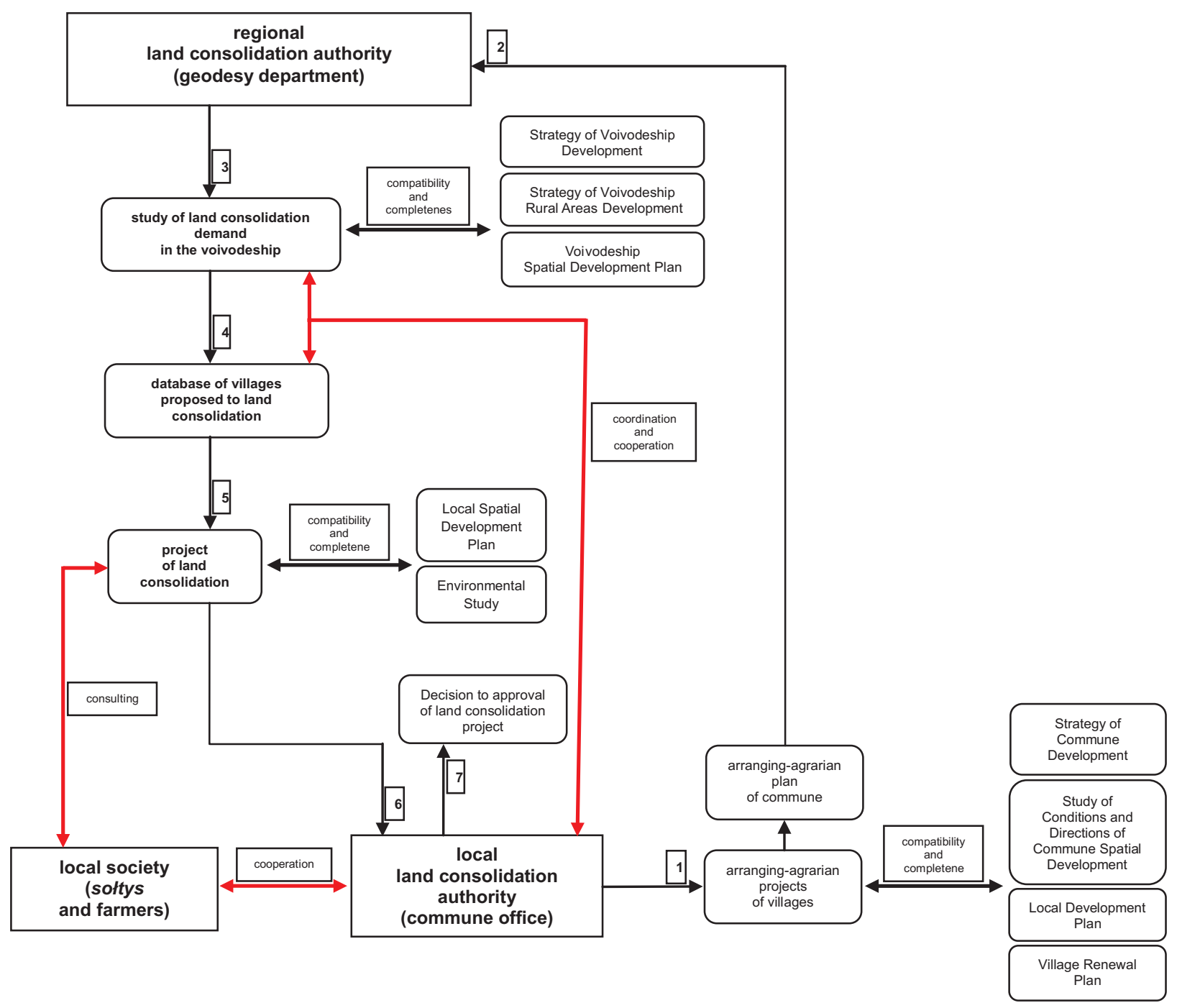

Fig. 2. The proposition of improving the policy of land consolidation in Poland. The numbering indicates various stages of formal procedures

The invaluable advantage of this operation is a complex assessment of farming importance within differed areas what is helpful in eliminating regions with less favourable natural and economic conditions of agricultural development, where land merging would be unjustified. Instead of this, non-agricultural purposes can be introduced, what proves the role of arranging-agrarian plans in creating long-term solutions for multifunctional countryside development. Furthermore, establishing appropriate administrative structures, and thanks to this, having sufficient administrative power in relation with strictly legal procedures, seems to be way forward of land consolidation effectiveness in Poland.

\section{Discussion and conclusion}

The focus of this article was to put emphasise on the weaknesses of land consolidation policy in Poland and presenting alternative option, which can improve the efficiency of legal procedures. This approach reinforces the role of legislation as an important factor streaming of land merging. However, against the background of these studies still raises the request of the number of implemented land consolidation projects as well 
as total merged acreage, which depend not only on well-organised formal procedures, but also on amount of funds and involvement of both, land consolidation authorities and participants. In this case improving the policy seems to be the first step to remedy the situation.

Additionally, implication of the new proposition can come across some hindrances. According to the existed studies (Woch 2006), the pace of land re-fragmentation and creation of secondary field chessboard exceeds the pace of initial land consolidation. In this case, there is no legal prohibition on land defragmentation for inheritance or sale purposes, but, even if the legal restriction became law, enforcing this rule would be met with a huge resistance. It can lead to conflicting state of affairs, because this injunction disagrees with the basic rights of landowners to dispose of their own land according to their wishes. Instead of this, another two possibilities can be taken into consideration. One of them is the imposition of high tax on inherited land, suggested among others by Manjunathaa et al. (2013), what in terms of subsequent land subdivision, can discourage farmers to continuing such practices. The second one, the participation of landowners in land consolidation costs, what for example in Western Europe is a common practise (van Dijk 2007), would be a sufficient limitation in land defragmenting and better suggestion as well.

Also left open is the matter of the substantiation of caring out of land consolidation in Poland. Some of experienced experts, like for example Woch (2001), Wierzchowski (2007), Di Falco et al. (2010), are concerned of the results of existing studies, which do not confirm particularly significant increase in income after land readjustment. It needs to be noted that reducing the number of parcels as well as adjusting the shape of fields to cultivated work, allows to cut down labour inputs and save working time. However, it is not always possible to eliminate the most troublesome factor - the distance between farms and fields, because despite the fact that parcels grouping and relocating had been conducted, it happens that the mileage still remains significant. This is because villages are too compacted and the agrarian land belonging to the given farmstead, can only adjacent it in a tiny piece. Here, the answer would be to loosen of households. Al- though this solution would brought the desired effect, its execution seems to be difficult due to the cost and technical obstacles. In addition, the huge variation of soil quality, especially in the areas falling within the influence of the last glaciations' zone, imposes on farmers the necessity of splitting parcels into smaller parts, according to crops' requirements, what in the result keeps high level of land fragmentation. In relation to natural conditions, it is difficult to suggest any good option to resolve this issue.

As for the farmers' attitude, the open interviews revealed that for Polish farmers' emotional value to farmland, the area cultivated by the same family for generations, very often is much more important than financial benefits obtaining after land relocation. It is especially observed within small family farms and dual-worked parttime farmers, who maintain farms only as a sideline. In contrary large-scale commercial farms are more favour to reducing problems of land fragmentation and poorly shaped parcels.

When comes to the results of land grouping and parcels relocation it cannot be overlooked the environmental side-effects. Taking into account low output in agriculture as well as technical and infrastructural backwardness of rural areas in Poland, it is not disputed that reorganization of agrarian structure and modernization rural areas are necessary. Yet, on the other hand, gaining of economic profits by improving agrarian structure and recovering infrastructure, can affect the landscape diversity as a consequence of decreasing number of mid-field balks, being field margins tiny uncultivated strips of lands, which demarcate land possession. Additionally, enlargement of arable plots done by removal of small biotopes, resulting in decline of biodiversity, not mention about lowering aesthetic values of landscape (Herzog 1998, Di Falco, Perrings 2005, Miranda et al. 2006, Sklenicka 2006). Undoubtedly, it has consequences on cultural landscapes, because it leads to more homogeneous landscape and the loss of cultural value (Pasakarnis et al. 2013). Moreover, there is a justified concern that land consolidation contributes towards the impoverishment, sometimes even destruction of Polish traditional agrarian landscape pattern, which is unique throughout the European Union countries. This contradicts the principle of 
the protection and preservation of cultural heritage and the maintenance of traditional agricultural landscapes is a challenge facing the EU (The Common Agricultural Policy after 2013). For this reason, land merging should be carried out only on highly fragmented areas with simultaneous keeping important value of natural and non-natural conditions for agricultural use.

Notwithstanding, it should be rethought how above concerns come true by real activities. Land consolidation in Poland is conducted a on a basis of pilot programmes, implemented on marginal scale and consolidated farmlands have a small contribution in total agricultural land. Moreover, consolidation work does not lead to monocultures shaping, which are created only as a result of land integration into a whole. Fortunately, under conditions of Polish agriculture, it is impossible to obtain such large-scale fields, because on the one hand, a large number of farmers manage of a relatively small acreage of land, and on the other hand, varied soil conditions or diversified land relief, effectively restrict these opportunities. Therefore, worries about loss of biodiversity, which definitely occur within post-grouping rural areas, and which rate depends on the intensity of the consolidation work, is questionable here. In addition, recently carried out land merging and relocation combines: rules of agrarian economics, for creating conditions for proper agricultural land management, with principles of rational landscaping, with respecting the ecological value, what was confirmed in this paper by presenting a good practice implementing in the Dolnośląskie Voivodeship. It should also be mentioned that in the mountains regions, in areas with varied terrain, susceptible to erosion processes, land consolidation would be harmful, because of erosion intensification (Baran-Zgłobicka, Zgłobicki 2010, Boardman, Poesen 2006). For this reason, it is really important to maintain a rational approach in a case of improving the agrarian pattern with application the tool that is the land consolidation.

Continuing the above plot, in Poland there is no legal obligation that would require state or local governments to prepare the demand of land consolidation, neither at the national, nor the regional or local levels. The existing provision of the legislation only authorizes this option. In a clearly way it shows that in Poland land consolidation, as a tool for management and development of rural areas, is still neglect. In contrary, in most Western European countries land consolidation is an integrated part of wider rural development context (Thomas 2006). This is because of the fact that land consolidation has connections to an extensive range of body of laws, such as: land use and planning, agriculture, environmental protection (Meuser 1992), and also, it is implemented with the Common Agricultural Policy as co-financing under the national rural development programme (Pasakarnis, Maliene 2010).

It should be added that Western European countries have long tradition in land consolidation performing as well as to CAP reforms adjusting. Apart from that, although land merging has been practiced in many European countries since many years (Lambert 1963), legal procedures of land consolidation in each country are different, depending on the historical and social conditions. For this reason it is not simply transferable both, knowledge and experience of Western land consolidation into Eastern European countries, what was suggested earlier by van Dijk (2003). Even if Western countries are successful in the field of land consolidation policy, it does not mean that all these good practices would be adequate to the Polish case.

All things considered, although suggestions relating to key-answer to the problem of faulty agrarian structure proposed in this paper can partly improve the situation, until cooperation and involvement between stakeholders participating in land consolidation process will not be shown grater commitment, land merging in Poland will still be faced with difficulties.

\section{References}

Act of 24 January 1968 on Land Consolidation and Exchanged, Dz.U. of 1968, No. 3, item 1097. Ustawa z 24 stycznia 1968 r. o scalaniu i wymianie gruntów, Dz.U. z 1968 r., nr 3, poz. 13.

Act of 8 March 1990 on Local Government, Dz.U. of 2001, No. 142, item 1591. Ustawa $z$ dnia 8 marca 1990 r. o samorzadzie gminy, Dz.U. z 2001 r., nr 142, poz. 1591, z późn. zm.

Act of 26 March 1982 on Land Consolidation and Exchange, Dz.U. of 2011, No. 185, item 1097. Ustawa z 26 marca 1982 
r. o scalaniu i wymianie gruntów rolnych, Dz.U. z 2011 r., nr 185, poz. 1097.

Act of 27 March 2003 on Spatial Planning and Development, Dz.U. of 2003, No. 80, item 717. Ustawa z 27 marca 2003 r. o planowaniu i zagospodarowaniu przestrzennym, Dz.U. z 2003 r., nr 80, poz. 717.

Act of 17 May 1989 of the Geodesic and Cartographic Law, Dz.U. of 2005, No. 240, item 2027. Ustawa prawo geodezyjne $i$ kartograficzne z 17 maja 1989 r., Dz.U. z 2005 r., nr 240, poz. 2027.

Act of 5 June 1998 on Province Government, Dz.U. No. 91, item 576. Ustawa z 5 czerwca 1998 r. o samorzadzie województwa, Dz.U. nr 91, poz. 576.

Act of 31 July 1923 on Land Consolidation, Dz.U. No 93, item 718. Ustawa z 31 lipca 1923 r. o scalaniu gruntów, Dz.U. nr 93, poz. 718 .

Act of 13 October 1998 - Regulations Implementing the Act Reforming Public Administration, Dz.U. No. 133, item 872. Ustawa $z 13$ listopada 1998 r. - Przepisy wprowadzajace ustawy reformujace administracje publiczna, Dz.U. nr 133, poz. 872.

Baran-Zgłobicka B., Zgłobicki W., 2012. Mosaic landscapes of SE Poland: should we preserve them? Agroforestry System 85: 351-365.

Bartolini F., Viaggi D., 2013. The common agricultural policy and the determinants of changes in EU farm size. Land Use Policy 31: 126-135.

Benedek J., 2000. Land reform in Romania after 1989: towards market oriented agriculture? In: P. Tillack, E. Schulze (eds.), Land Ownership, Land Markets and Their Influence on the Efficiency of Agricultural Production in Central and Eastern Europe. Proceedings of the IAMO Seminar, Halle/Saale, Germany.

Boardman J., Poesen J., 2006. Soil erosion in Europe: major processes, causes and consequences. In: J. Boardman, J. Poesen (eds.), Soil erosion in Europe. Wiley, Chichester: 479-487.

Deininger K., Sarris A., Savastano S., 2004. Rural land markets in transition: evidence from six Eastern European Countries. Quarterly Journal of International Agriculture 43: 361-390.

Di Falco S., Perrings C., 2005. Crop biodiversity, risk management and the implications of agricultural assistance. Ecological Economics 55: 459-466.

Di Falco S., Penov I., Aleksiev A., van Rensburg T., 2010. Agrobiodiversity, farm profits and land fragmentation: evidence from Bulgaria. Land Use Policy 27: 763-771.

FAO, 2008. Opportunities to mainstream land consolidation in rural development programmes of the European Union. Land Tenure Policy Series, Rome.

Grossman M.R., Brussaard W., 1992. Agrarian land law in the western world. CAB International, Oxford.

Herzog F., 1998. Streuobst: a traditional agroforestry system as a model for agroforestry evelopment in temperate Europe. Agroforesty Systems 42: 61-80.

Instruction No. 1 of the Agriculture and Food Minister on land consolidation of 24 March 1983 GZ-g-630-1/83. Instrukcja nr 1 Ministra Rolnictwa i Gospodarki Żywnościowej o scalaniu gruntów z dnia 24 marca 1983 r. GZ-g-630-1/83.

Kabat L., Hagedorn K., 1997. Privatisation and decollectivisation policies and resulting structural changes of agriculture in Slovakia. In: J.F.M. Swinnen et al. (eds.), Agricultural Privatisation, Land Reform and Farm Restructuring in Central Europe. Ashgate, Aldershot.

Lambert A.M., 1963. Farm Consolidation in Western Europe. Journal of the Geographical Association 48: 31-48.
Local Data Bank. Online: www.stat.gov.pl/bdl (accessed 12 January 2013).

Manjunathaa A.V., Asif Reza Anikc, Speelmand S., Nuppenaua E.A., 2013. Impact of land fragmentation, farm size, land ownership and crop diversity on profit and efficiency of irrigated farms in India. Land Use Policy 31: 397-405.

Markuszewska I., 2013. Changes of agricultural landscape pattern-non-natural driving forces analyzing based on the North-Western Region of Poland. Questiones Geographic 32(1): 5-14.

Meuser F.J., 1992. Europäische Fachtagung Flurbereinigung im Jahre 1988 - Analyse der Ergebnisse (Expert Meeting on Land Consolidation in Germany 1988 - Analysis and Findings). Lehrstuhl für Bodenordnung und Landentwicklung. Technische Universität München, 15/1992.

Miranda D., Crecente R., Alvarez M. F., 2006. Land consolidation in inland rural Galicia, N.W. Spain, since 1950: An example of the formulation and use of questions, criteria and indicators for evaluation of rural development policies. Land Use Policy 23: 511-520.

Pasakarnis G., Maliene V., 2010. Towards sustainable rural development in Central and Eastern Europe: Applying land consolidation. Land Use Policy 27: 545-549.

Pasakarnis G., Morley D., Maliene V., 2013. Rural development and challenges establishing sustainable land use in Eastern European countries. Land Use Policy 30: 703-710

Sklenicka P., 2006. Applying evaluation criteria for the land consolidation effect to three contrasting study areas in the Czech Republic. Land Use Policy 23: 502-510.

Statistical Yearbook of Agricultural, 2011. Central Statistical Office. On-line: http:/ / www.stat.gov.pl/cps/rde/xbcr/ gus/rs_rocznik_rolnictwa_2011.pdf (accessed 27 December 2012).

Sonnenberg J., 2002. Fundamentals of Land Consolidation as an Instrument to Abolish Fragmentation of Agricultural Holdings. Paper, FIG XXII International Congress Washington, D.C. USA.

Tenkanen A., 1994. Environmental Aspects of Land Consolidation. Commission 7/Paper TS 704.3. FIG/XX Congress, Melbourne, Australia.

The Analysis of demand for land consolidation work in villages of the Dolnoślaskie Voievodship, 2010. Analiza zapotrzebowania na scalanie gruntów rolnych wsi województwa dolnoślaskiego. Online: wgik.dolnyslask.pl (accessed 15 October 2012).

The Common Agricultural Policy after 2013. Summary Report. On-line: ec.europa.eu/agriculture/cap-post-2013/debate/report/summary-report_en.pdf (accessed 15 February 2013).

Thomas J., 2006. Property rights, land fragmentation and the emerging structure of agriculture in Central and Eastern European countries. Journal of Agricultural and Development Economics 2: 225-275.

Wierzchowski M., 2007. Przestrzenne, ekonomiczne i społeczne problemy scalania i wymiany gruntów (Spatial, economic and social problems of land consolidation and Exchange). Instytut Rozwoju Miast, Kraków.

Woch F., 2001. Optymalne parametry rozłogu gruntów gospodarstw rodzinnych dla wyżynnych terenów Polski (Optimal parameters of plot distribution pattern of family farms in hilly areas of Poland). IUNiG, Rozpr. Habilitacyjna, Puławy.

Woch F., 2006. Kompleksowe scalanie gruntów rolnych i leśnych oraz jego wptyw na środowisko (Comprehensive farmland and forest land consolidation and its impact on the environment). IUNiG, Mat. Szkol., 93, Puławy. 
van Dijk T., 2003. Scenarios of Central European land fragmentation. Land Use Policy 20: 149-158.

van Dijk T., 2007. Complications for traditional land consolidation in Central Europe. Geoforum 38: 505-511.

Vitikainen A., 2004. An Overview of Land Consolidation in Europe. Nordic Journal of Surveying and Real Estate Research 1: 25-44.

Voltr V., 2000. EU accession and the land market in the Czech Republic. In: P. Tillack, E. Schulze (eds.), Land Ownership,
Land Markets and their influence on the efficiency of agricultural production in Central and Eastern Europe. Proceedings of the IAMO Seminar, Halle/Saale, Germany.

Vranken L., Noev N., Swinnen J., 2004. Fragmentation, abandonment and coownership: transition problems of the Bulgarian Land Market. Quarterly Journal of International Agriculture 43: 391-408. 